\title{
Numerical and experimental analysis of the behavior of structural elements composed of double lattice panels filled with cast-in-place concrete
}

\section{Análise numérica e experimental do comportamento de elementos estruturais compostos por painéis duplos treliçados preenchidos com concreto moldado no local}
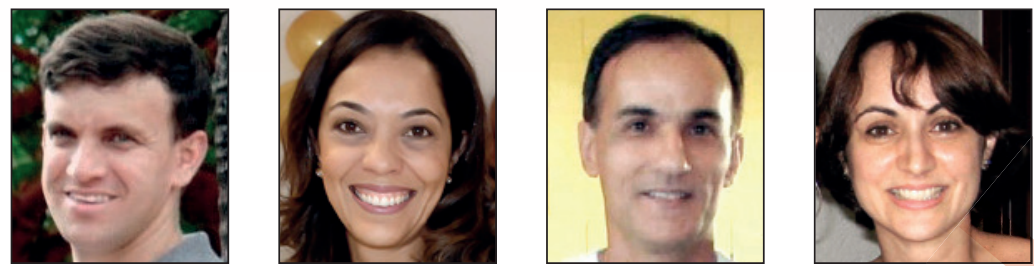

B. M. LACERDA a benicio_lacerda@hotmail.com

M. C. V. LIMA a

macris@ufu.br

F. A. R. GESUALDO ngesualdo@ufu.br

V. C. CASTILHO a castilho@feciv.ufu.br

\begin{abstract}
An experimental and numerical investigation was conducted into the factors that interfere in the shear strength of the concrete-concrete interface in structures composed of double lattice panels subjected to direct shear stress. The experimental program consisted of testing 26 direct shear models with varying widths of concrete filling of $7 \mathrm{~cm}, 9 \mathrm{~cm}$ and $13 \mathrm{~cm}$, with smooth and rough interfaces, as well as different concrete compressive strengths in the filled region. The numerical modeling, which was performed with ANSYS software, employed solid finite elements, bar elements and contact elements, taking into account the non-linearity of the materials involved. The analyses of the experimental results under direct shear indicated that the transfer of stresses at the interface occurred with loss of adhesion. The numerical simulations indicated that the higher the geometric ratio of reinforcement the higher the direct shear strength of the structural model. In general, the slip of the models with smooth interfaces was 2 or 3 times greater than the models with rough surfaces. Numerically, the models with smooth interfaces showed a $36.61 \%$ gain in shear strength when the compressive strength in the region filled with concrete increased from $20 \mathrm{MPa}$ to $28.4 \mathrm{MPa}$.
\end{abstract}

Keywords: numerical modeling, experimental analysis, double panels lattice, direct shear, nonlinear analysis.

\section{Resumo}

Este estudo apresenta uma investigação experimental e numérica dos fatores que interferem na resistência ao cisalhamento da interface entre concretos de estruturas formadas por painéis duplos treliçados, submetidos ao cisalhamento direto. O programa experimental foi realizado por meio do ensaio de 26 modelos submetidos ao cisalhamento direto, com a largura do concreto de preenchimento variando de $7 \mathrm{~cm}, 9 \mathrm{~cm}$ e $13 \mathrm{~cm}$, com interfaces lisas e rugosas, além de diferentes resistências à compressão do concreto na região de preenchimento. A modelagem numérica foi feita com a utilização do software ANSYS e consistiu no emprego de elementos finitos sólidos, elementos de barras e elementos de contato, levando-se em conta a não linearidade física dos materiais envolvidos. A análise dos resultados experimentais mostra que, sob cisalhamento direto, a transferência de tensões na interface ocorre com perda de adesão. A simulação numérica indica que quanto maior a taxa de armadura que cruza a interface maior é a resistência ao cisalhamento direto. Em geral, o deslizamento relativo observado nos modelos com interface lisa é em torno de 2 a 3 vezes maior que nos modelos com interface rugosa. Numericamente, observa-se um ganho na resistência cisalhante de $36,61 \%$ ao elevar a resistência à compressão na região de preenchimento do concreto de $20 \mathrm{MPa}$ para $28,4 \mathrm{MPa}$, para os modelos de interfaces lisas.

Palavras-chave: modelagem numérica, análise experimental, painel duplo treliçado, cisalhamento direto, análise não linear.

Universidade Federal de Uberlândia, Faculdade de Engenharia Civil, Uberlândia, MG, Brasil. 


\section{Introduction}

Partial cross-section precast concrete structural elements have been employed in Brazil for the construction of small buildings, as a rational approach for using prefabricated components.

The Brazilian technical standard ABNT NBR 9062:2006 defines parts composed of partial cross-sections as concrete elements interconnected by separate forming systems, which act as a single part subjected to the loads imposed upon it after its solidification. Partial cross-section parts are used because they reduce the consumption of formwork and shoring and are an option for lower weight elements for small and medium-sized applications, which can be transported during their assembly.

The technical literature describes investigations of the shear transfer mechanism across new and existing concrete interfaces by many authors, e.g., Hofbeck, Ibrahim and Mattock (1969); Hsu, Mau and Chen (1987); Bass, Carrasquillo and Jirsa (1989), Araújo $(1997,2002)$ and Kabir (2005). The structural behavior of precast concrete sandwich panels has also been studied both experimentally and theoretically, as presented by Benayoune et al. (2008). According to the ABNT NBR 6118:2014 standard, requirements that ensure the quality and structural strength, service performance and durability of concrete structures must be met during the construction and service stages.

In this context, this study aims to examine the structural behavior of precast concrete double lattice panels by means of numerical modeling and experimental analysis. The aim is to determine whether these components behave monolithically under direct shear. The interface bonds in concrete with different ages should be evaluated, once the mechanical behavior of the precast element is influenced by shear load transfer at the interface.

The structural response at the interface of the double lattice panel filled with cast-in-place concrete (CPC) is assessed taking into account the effect of variations in the width of filler concrete, the

Figure 1 - Details of a double lattice panel

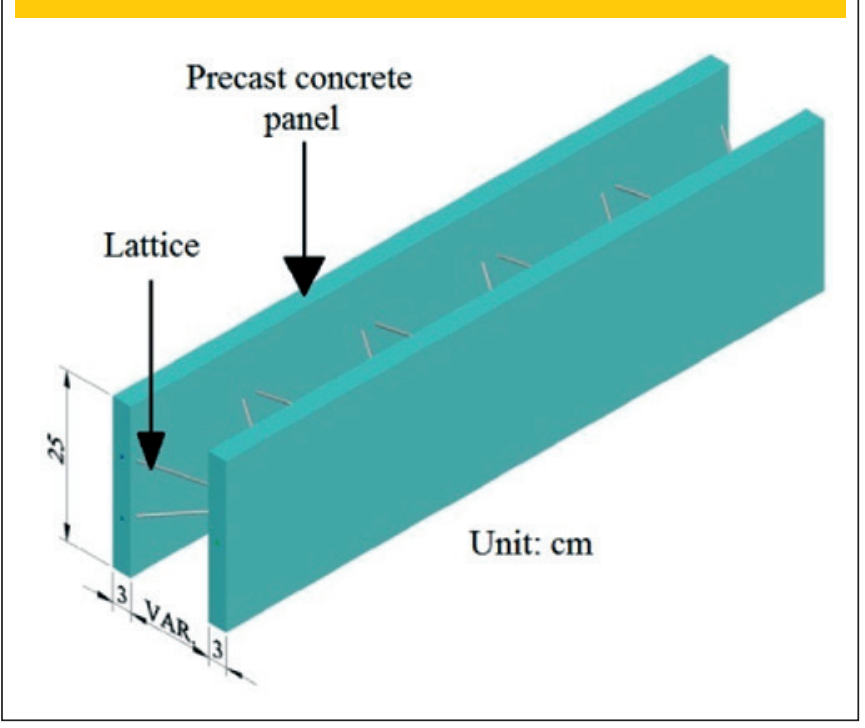

compressive strength of the concrete, and the surface roughness of the bonding interface.

\section{Double lattice panels}

The double lattice panel consists of two precast concrete (PCC) plates about $3 \mathrm{~cm}$ to $3.5 \mathrm{~cm}$ thick and about $25 \mathrm{~cm}$ high. The plates are interconnected by means of an electro-welded lattice frame, with the distance between the plates varying according to the design requirement (Figure 1).

Some of the advantages of using this structural system at construction sites, according to El Debs (2000), are: faster production; lower consumption of concrete; lower expenses with riggers and carpenters, since the panel serves as formwork; substantial reduction in timber and scaffolding; and reduction of wastes generated during the construction phase, which ensures greater savings in construction site cleaning costs. In the case of precast partial cross-sections - the focus of this work, double lattice panels are an option for the use of the technique, preserving the overall characteristics of monolithic concrete structures.

However, structural elements composed of double lattice panels are limited in terms of shape, e.g., curved parts, and size, because they are built by hand; hence, a heavier component would make the construction process very difficult.

Double lattice panels are bonded with cast-in-place concrete, because this bond is simple to make.

According to Araújo (2002), the behavior of these interface bonds in concrete should be evaluated, because the fact that they have different ages and characteristics can influence their mechanical behavior, such as shear load transfer at the interface.

Precast panels are manufactured with fixed thicknesses, but their dimensions of height and width vary, and these panels can be used in various applications (Figure 2).

Each side of a double panel is concreted at an interval of 24 hours. After solidification, the structural behavior is influenced by shear load transfer at the interface. Solidification of the double lattice panel may lead to differential shrinkage and creep in the precast concrete (PCC) and cast-in-place concrete (CPC), since their ages and characteristics differ. Adherence between contact surfaces is an important parameter to be investigated, because it influences the transfer of shear stresses at the interface.

\section{Shear transfer mechanisms between concrete surfaces}

Shear transfer at the interface between different ages concrete can be divided into transfer through the contact surface and through the reinforcement transverse to this surface.

Shear load transfer at the contact surface between two concrete elements occurs by bonding and can be divided into:

- Adhesion: this is the first mechanism that is triggered at the interface between concrete components and is limited to low shear stress once it is removed by slip.

- Friction: after the breakup of the adhesive mechanism, the strength at the interface of the member can be ensured by the friction existing between the contact surfaces. This occurs when there is a small slip at the interface of the member due to the presence of transverse stresses. This portion of frictional load transfer at the interface is influenced directly by surface roughness. 


\section{Figure 2 - Application of double panels in shear wall, column, foundations and beams}

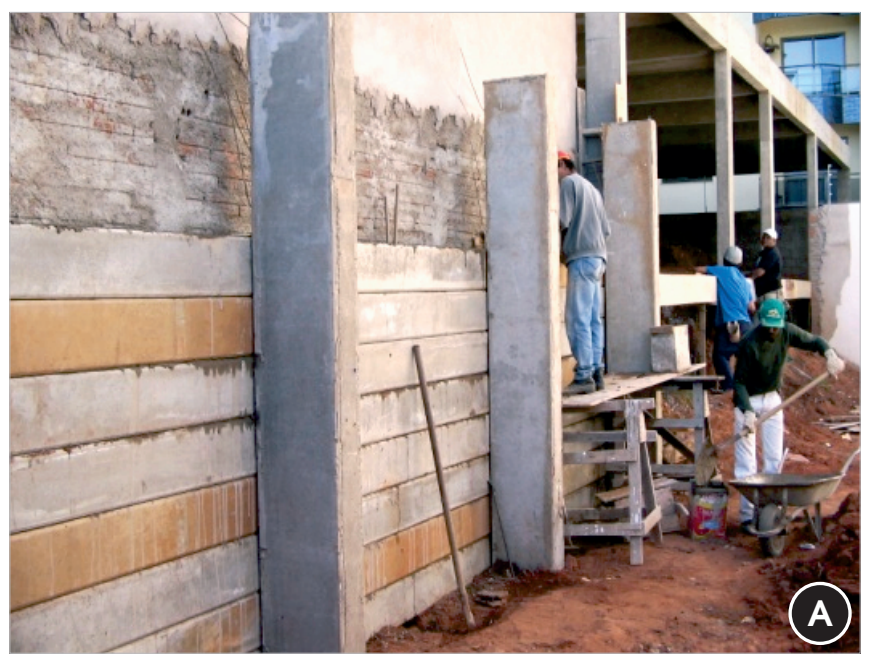

Double panel shear wall

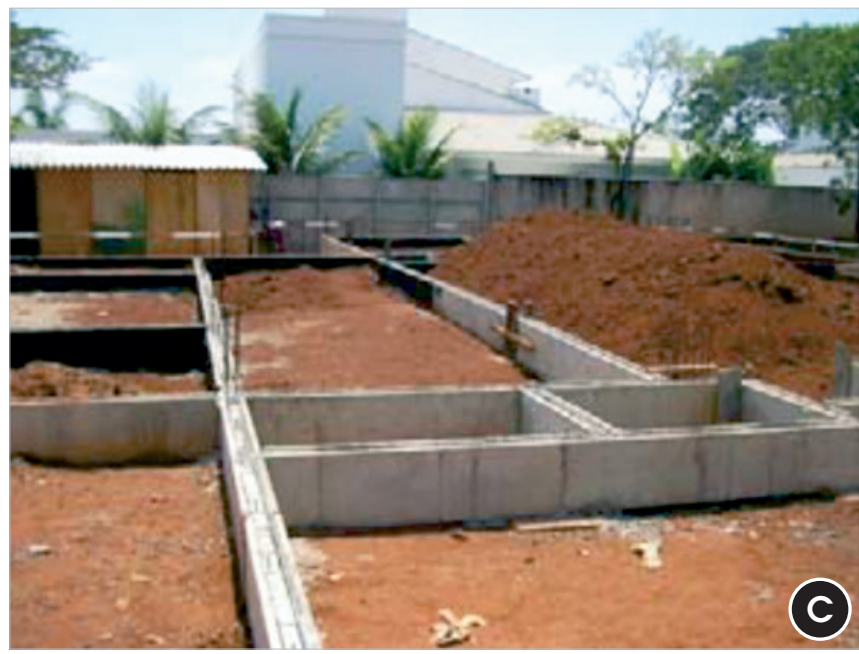

Foundations

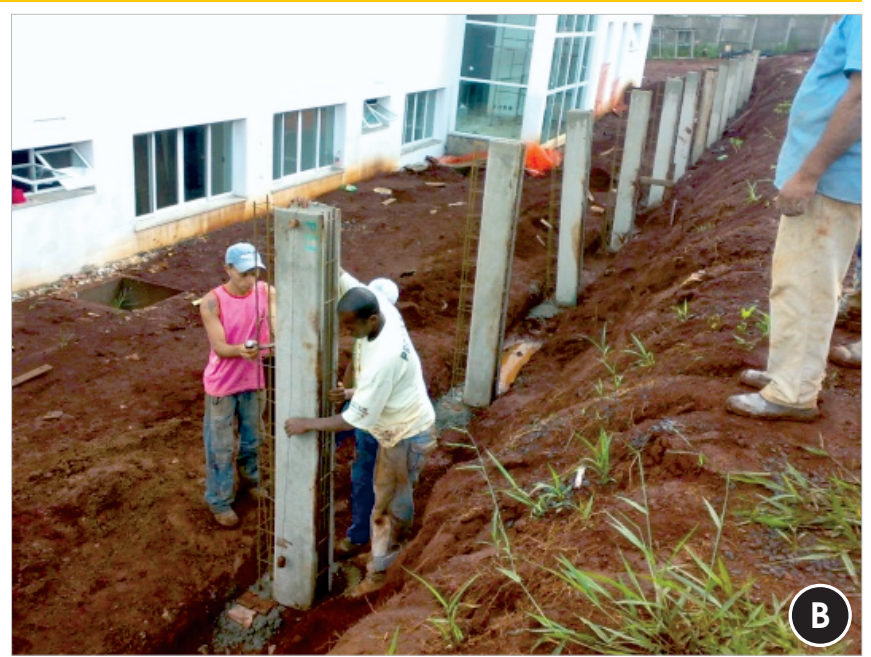

Column

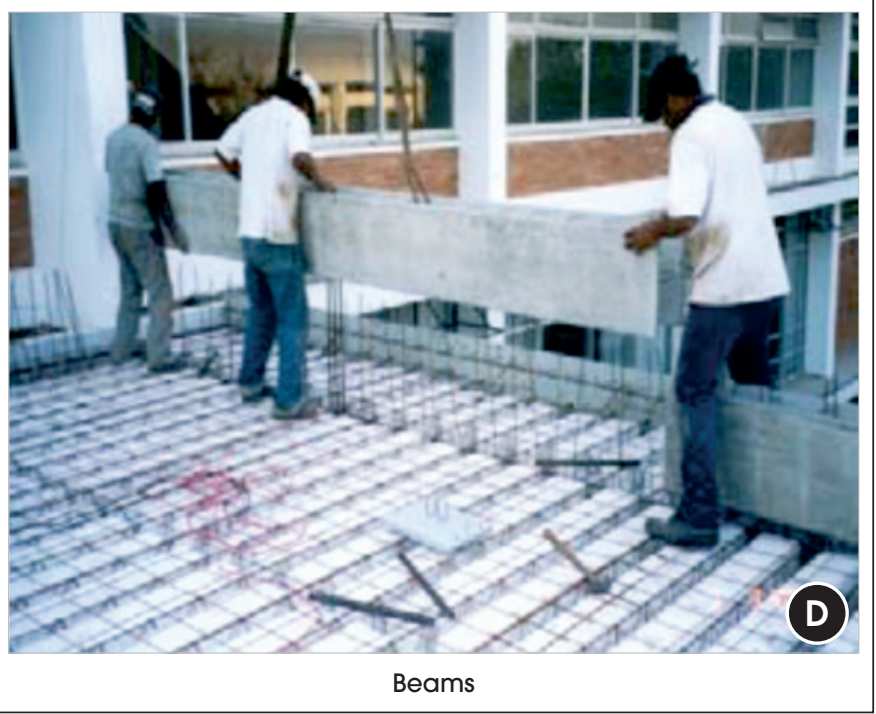

Mechanical: mechanical load transfer occurs when there is relative slipping between two contacting surfaces. This type of transfer occurs by mechanical engagement when these slips are shear loaded. On rough surfaces, mechanical engagement is ensured by the coarse aggregate at this interface.

When slip occurs on a surface, the transverse reinforcement at the interface contributes to transfer shear stresses by dowel action. According to Araújo (2002), the shear resistance by dowel action due to the transverse reinforcement generally presents lower values than the frictional and mechanical action. The transverse reinforcement increases the frictional resistance between the surfaces in response to a load normal to the interface. If the surface is rough, transverse clearance may occur, which, added to the slip between the surfaces, may cause elongation of the rebar (Figure 3).

The frictional resistance between the contact surfaces increases due to rebar reactions, creating normal compressive stress at the interface. Araújo (2002) explains that an interface must be clearly defined for concrete members with a high concentration of rebars normal to the plane of the interface and subjected to tangential loads. Otherwise, cracks inclined towards the shear plane are formed (Figure 4).

\section{Experimental program}

The experimental program consisted of testing 26 direct shear models, in the form of $50 \mathrm{~cm}$ high prismatic models, under increasing loads. The variables considered in the analysis of these models were: internal thickness of the panel, corresponding to the width of the concrete filling, roughness of the concrete-concrete interface (smooth or rough), and compressive strength of the cast-in-place concrete (CPC). The widths of the region filled with CPC were 7 $\mathrm{cm}, 9 \mathrm{~cm}$ and $13 \mathrm{~cm}$. The compressive strengths of the CPC were 


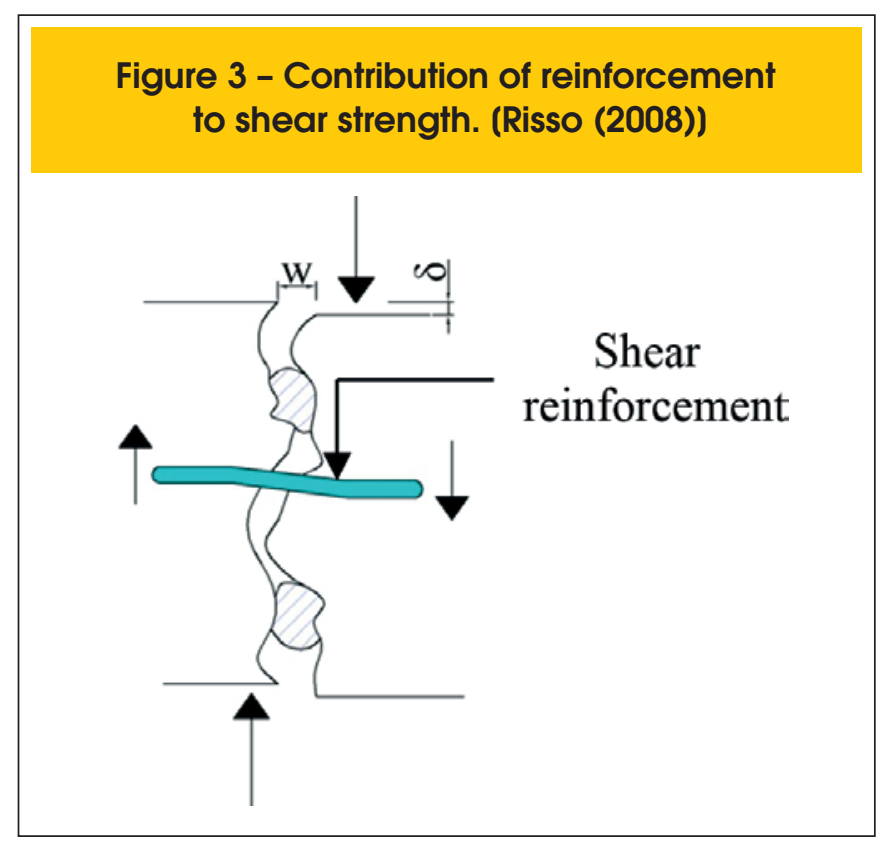

$20 \mathrm{MPa}, 29 \mathrm{MPa}$, and 28.4 MPa. The precast concrete (PCC) panels showed a compressive strength of $27.5 \mathrm{MPa}$. The surfaces of the interfaces were considered smooth $(S)$ and rough $(R)$.

\subsection{Direct shear test of the double panels}

The external sides of the panels were on average $3 \mathrm{~cm}$ thick. One of the sides of the panel was cast first (Figure 5a), and the other side was cast three days later (Figure $5 \mathrm{~b}$ ). The precast concrete elements are interconnected by means of electro-welded lattices and stirrups.

The second step consisted of filling the models with CPC between
Figure 4 - Cracks inclined toward the shear plane at the interface. (Araújo (2002))

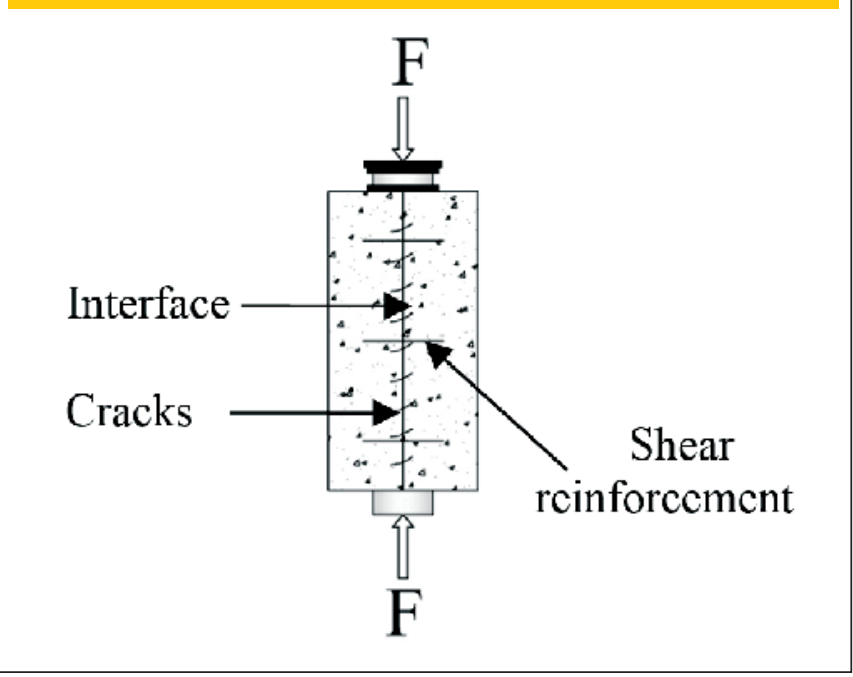

the PCC layers of the panel, resulting in a structural element with concrete of different ages. This step was performed in the Structures Laboratory of the Federal University of Uberlandia (Brazil).

The surface of the PCC-CPC interfaces of one of the tested series was roughened by waterblasting the aggregates and then cleaning them (Figure 6). The interfaces of the other series were left untouched after concreting the panel, i.e., without water blasting, and were considered smooth in this study. Figure 7 shows details of the reinforcement and dimensions of the models.

In the direct shear tests, an increasing load was applied upon the central element in the longitudinal direction of the CPC surface in the filled region. Wooden apparatuses were built and fixed onto

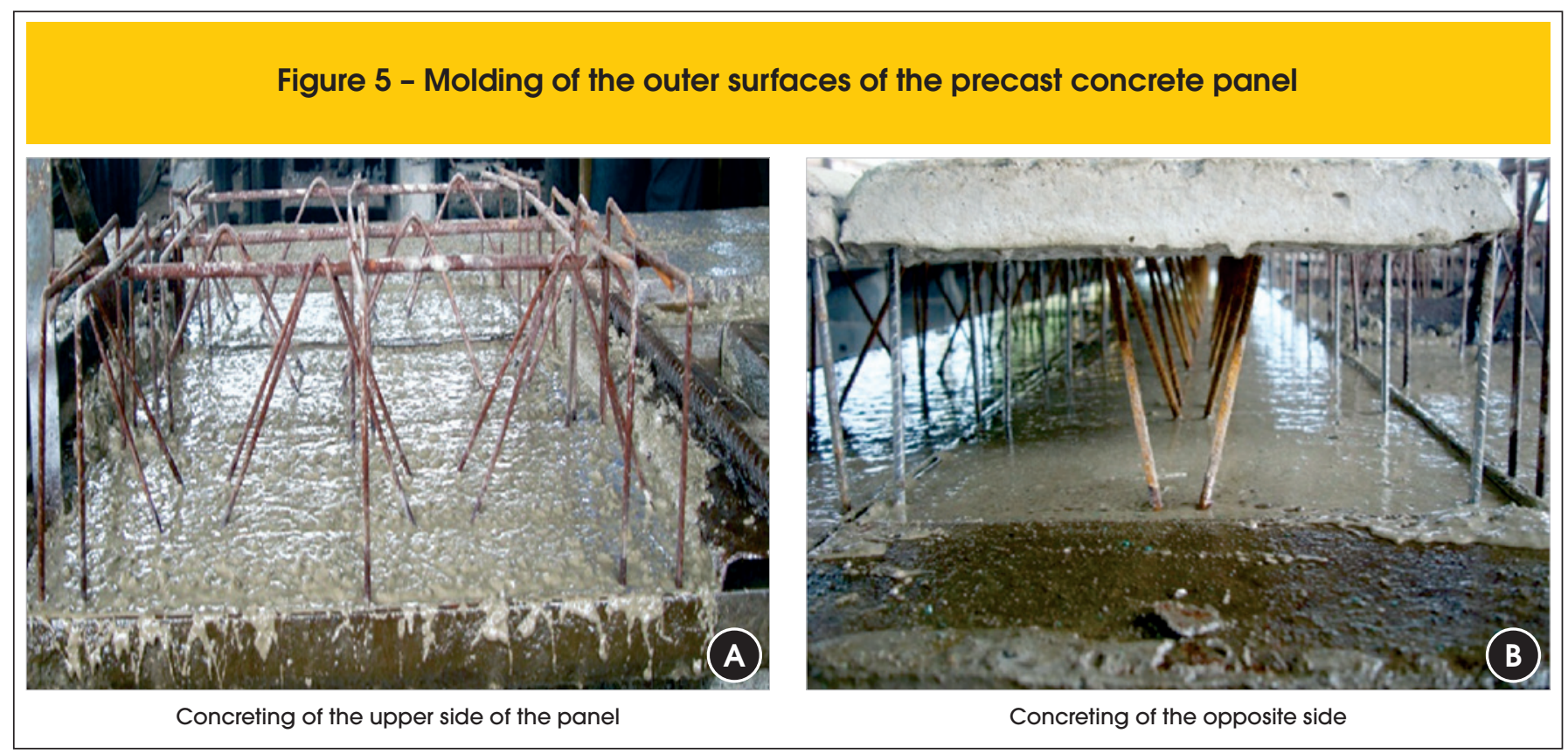




\section{Figure 6 - Panel with exposed coarse aggregate}

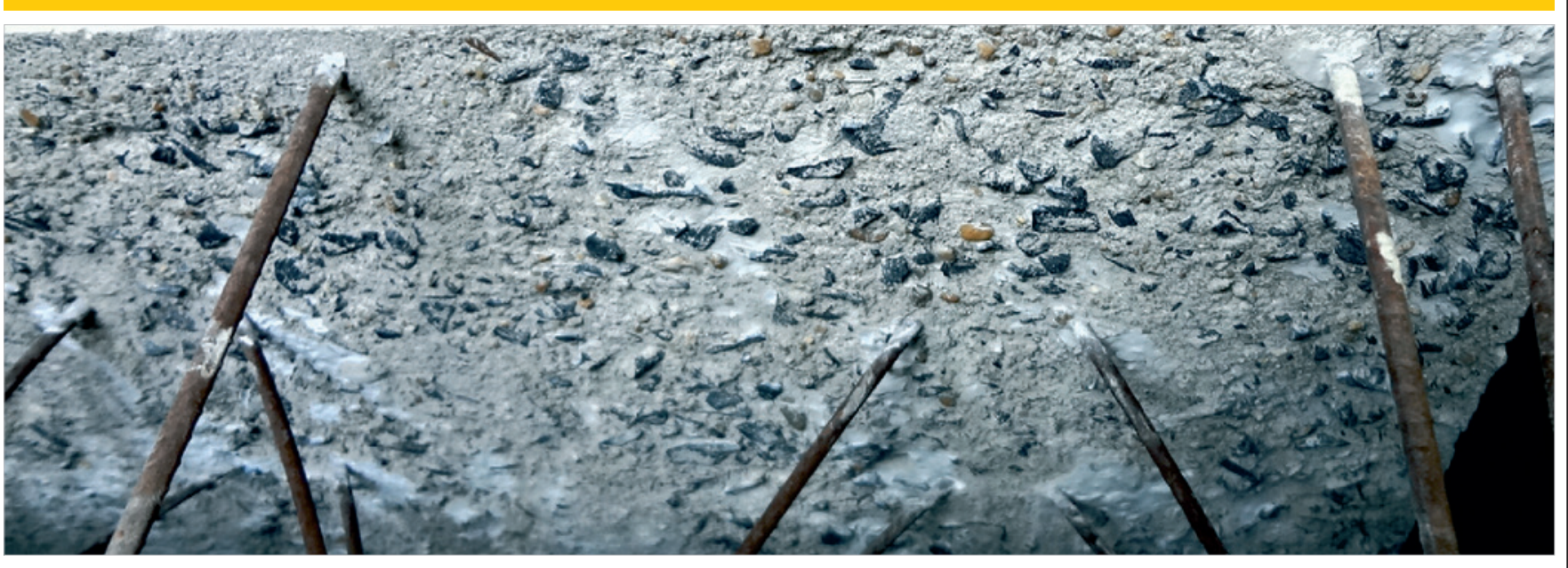

the PCC to measure the displacement at the concrete-concrete interface. Loading was applied in a universal testing machine with $600 \mathrm{kN}$ capacity.

The identification of each model of the tested series is identified as follows: XS/Y-Exp \# for smooth interfaces and XR/Y-Exp \# for rough interfaces. The value of $X$ corresponds to the width of the concrete filled region (CPC). The letters $S$ (smooth) or $\mathrm{R}$ (rough) correspond to the type of interface. This is followed, after the slash, by the $Y$ value of the compressive strength of the CPC. Lastly, the experimental model is designated Exp \#, as indicated in Table 1. The compressive strength of the PCC was about 27.5 $\mathrm{MPa}$ in all the tests.

Figure 8 shows a schematic diagram of the positioning of the wooden apparatus and the area where loads were applied, while Figure 9 shows the positioning of the transducers during the test.

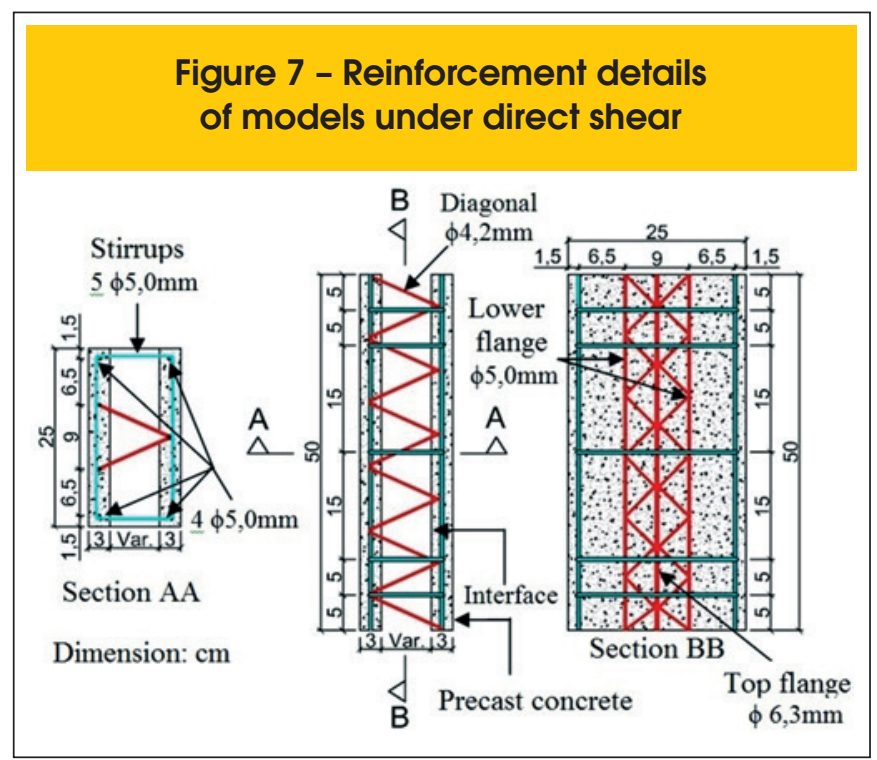

\section{Numerical modeling}

The numerical modeling of the direct shear models was performed using the elements SOLID65, SOLID185, LINK8, TARGE170 and CONTA174, which are available in the ANSYS software library to simulate the constituent parts of physical models. These elements were applied to simulate the behavior of concrete, steel, and the region of contact between the surfaces of concrete of different ages and of the contact with the steel plate on which double lattice panel was supported.

The element SOLID65 was used to simulate the PCC and CPC. This element consists of eight nodes with three degrees of freedom per node: translation in the nodal $\mathrm{x}, \mathrm{y}$ and $\mathrm{z}$ directions, and it can undergo tensile cracking, compressive crushing and plastic deformation.

LINK8 was applied to simulate the longitudinal framing and stirrups of the physical models. LINK8 has three degrees of freedom per

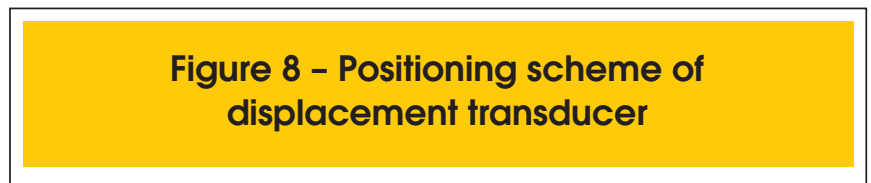

\section{FRONT VIEW}

SIDE VIEW

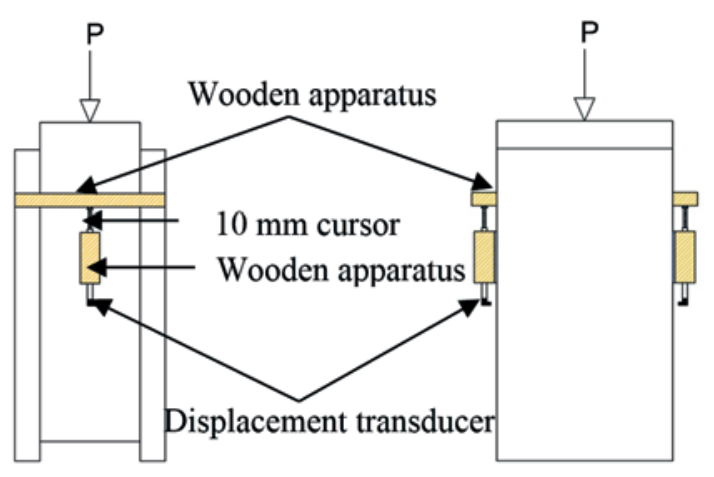




\begin{tabular}{|c|c|c|c|c|}
\hline \multicolumn{5}{|c|}{ Table 1 - Identification of the direct shear tested models } \\
\hline Series & Model & Internal width $(\mathrm{cm})$ & Type of surface shear & $f_{c}(M P a)$ \\
\hline A & 7S/20 - Exp \# & 7 & Smooth & 20 \\
\hline B & 9S/20 - Exp \# & 9 & Smooth & 20 \\
\hline C & $13 S / 20$ - Exp \# & 13 & Smooth & 20 \\
\hline D & $7 R / 29$ - Exp \# & 7 & Rough & 29 \\
\hline$E$ & 9R/29 - Exp \# & 9 & Rough & 29 \\
\hline $\mathrm{F}$ & 13R/29 - Exp \# & 13 & Rough & 29 \\
\hline$G$ & 7S/28.4 - Exp \# & 7 & Smooth & 28.4 \\
\hline $\mathrm{H}$ & 9S/28.4 - Exp \# & 9 & Smooth & 28.4 \\
\hline I & $13 S / 28.4$ - Exp \# & 13 & Smooth & 28.4 \\
\hline
\end{tabular}

node, i.e., translation in the nodal directions $x, y$ and $z$. This element can only simulate tension and compression forces, and can undergo plastic deformation, elongation and large displacements. The finite element TARGE170 was used to represent various "target" surfaces of contact surface elements associated with the element CONTA174. These elements simulate the contact of the surface at the interface of the concrete-to-concrete bond of the models. The pair of contacts represented by the elements TARGE170 and CONTA174 allows friction and cohesion to be con- sidered, as well as slipping between the bond surfaces. The friction coefficient considered in the numerical analysis was 0.6 for smooth surfaces and 1.0 for rough surfaces.

Figure 10 illustrates the discretization of the finite element used in the models subjected to direct shear, showing the indispensable condition of matching nodes with the nodes of the solid elements (CPC and PCC) to generate a stable model, using LINK8 (pinned nodes).

With regard to the physical nonlinearity of concrete, the concrete model was used to represent the behavior of CPC and PCC,

\section{Figure 9 - Positioning of displacement transducer in direct shear test}

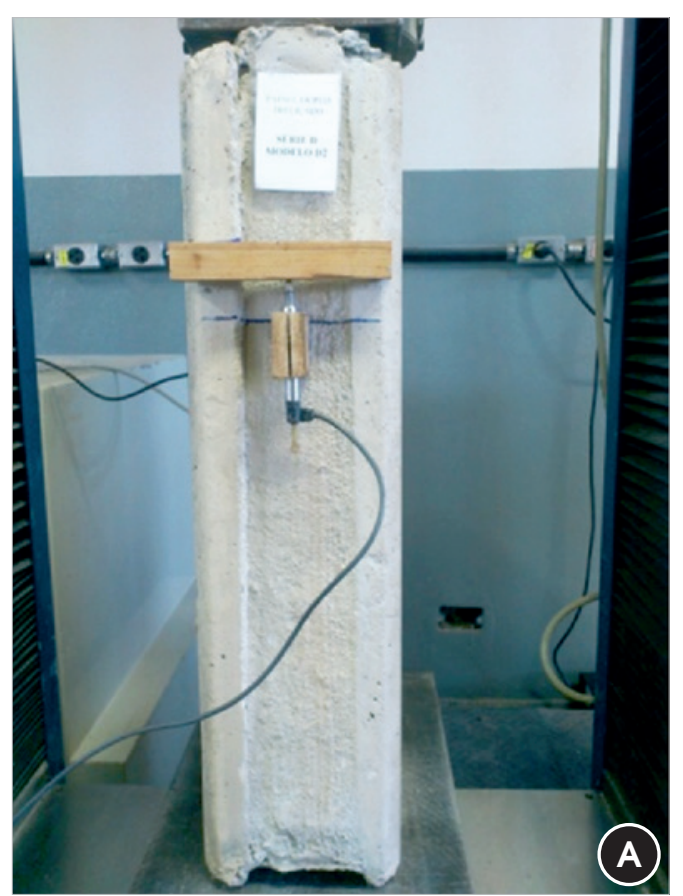

Transducer positioned on side A (front view)

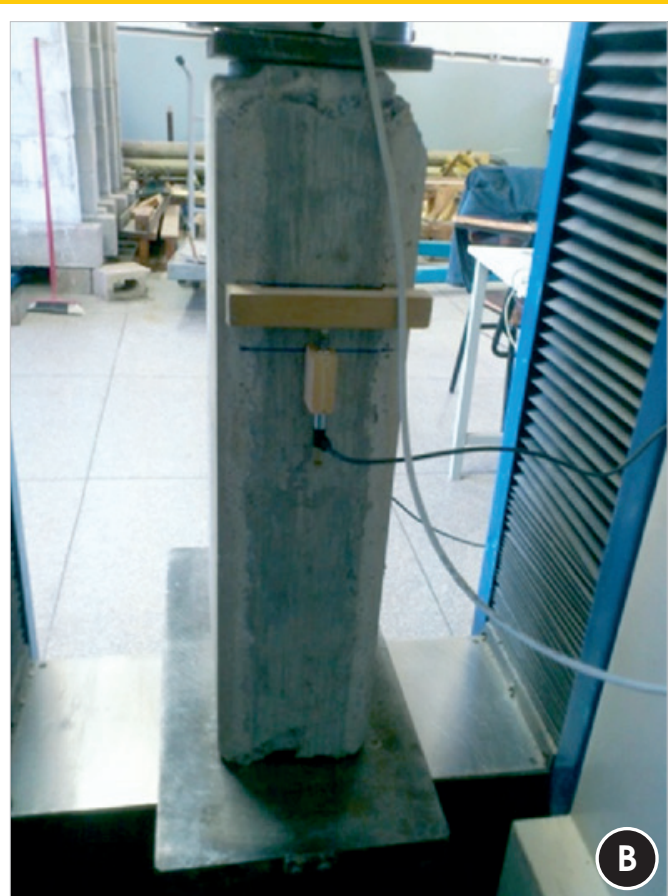

Transducer positioned on side B (back view) 


\section{Figure 10 - Direct shear model simulated with ANSYS}

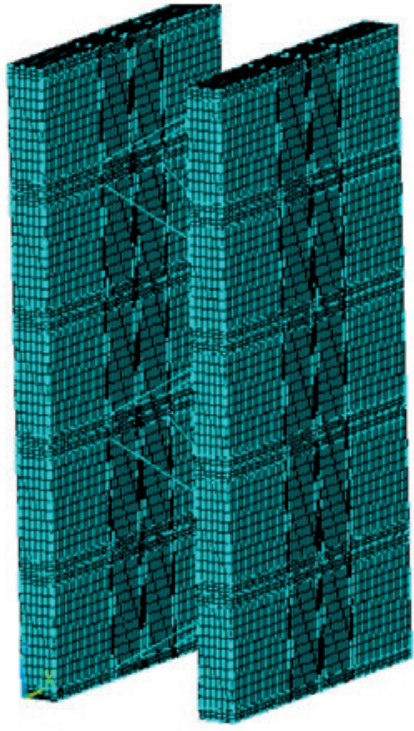

A

Solid and truss finite elements between PCC

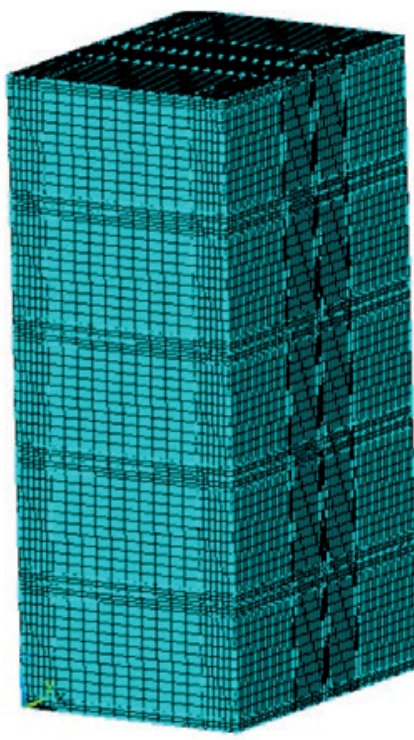

B

Precast and cast in place concrete mesh

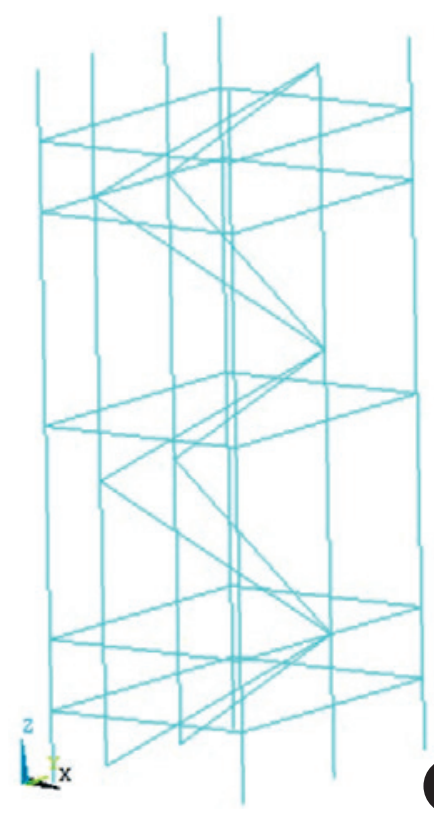

Link8 elements because it allows the material's failure to be predicted, presenting yielding, cracking and crushing based on Willam-Warnke criterion (Figure 11). The bilinear isotropic hardening model is adopted for steel behaviour (Figure 12). This model applied in LINK8 follows the von Mises yield criterion and lists the yield stress of steel, its modulus of elasticity and its density.

The convergence method for solving the nonlinear system applied here was the full Newton-Raphson method, which, according to
Oliveira (2007), allows the tangent stiffness matrix to be updated at each iteration. The adaptive descent feature was activated simultaneously to the full Newton-Raphson process. This feature should be used when applying elements of surface contact and is only valid when the full Newton-Raphson process is applied. In order to improve the convergence for the physical nonlinear analysis, the line search feature was enabled. This feature multiplies the incremental displacement vector by a scale factor between 0 and 1 .

\section{Figure 11 - Stress $\mathrm{x}$ strain concrete behavior (Unit: kN; cm) (Ansys v.11)}

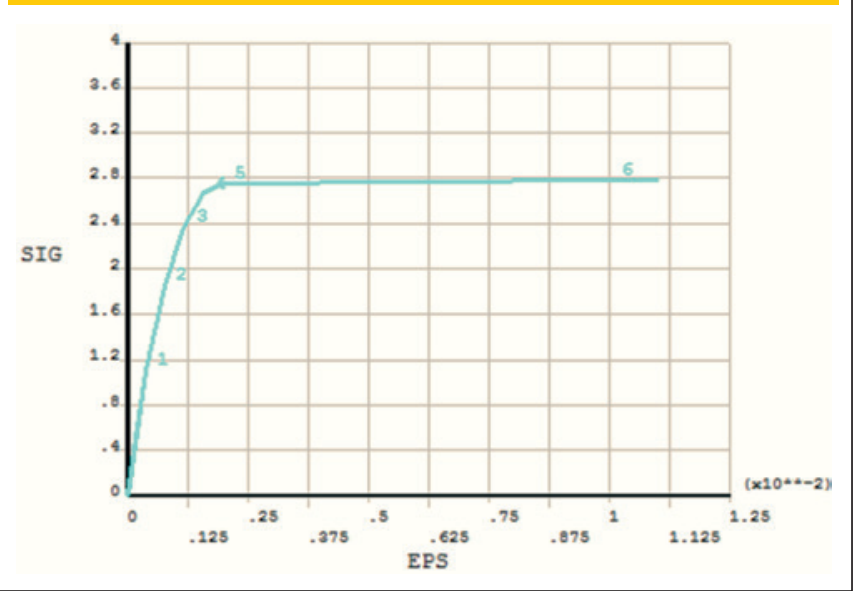

Figure 12 -Stress $x$ strain steel behavior (Unit: kN; cm) (Ansys v.11)

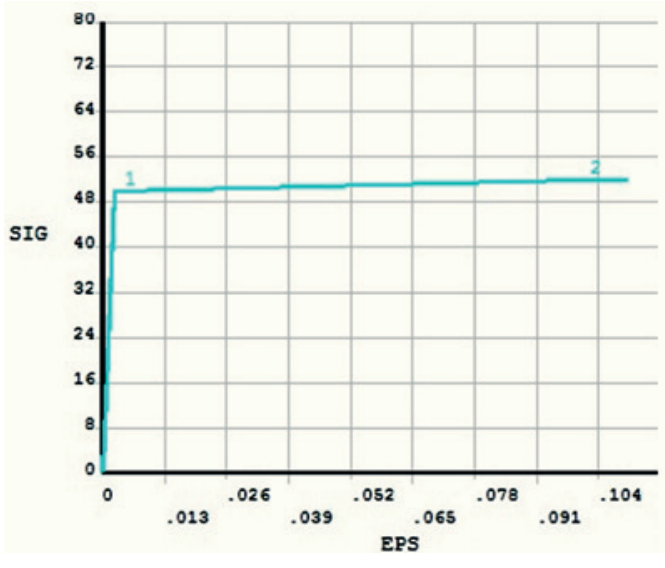


Figure 13 - Diagram of force vs. relative slip at the interface in Series C, F and I $(13 \mathrm{~cm})$

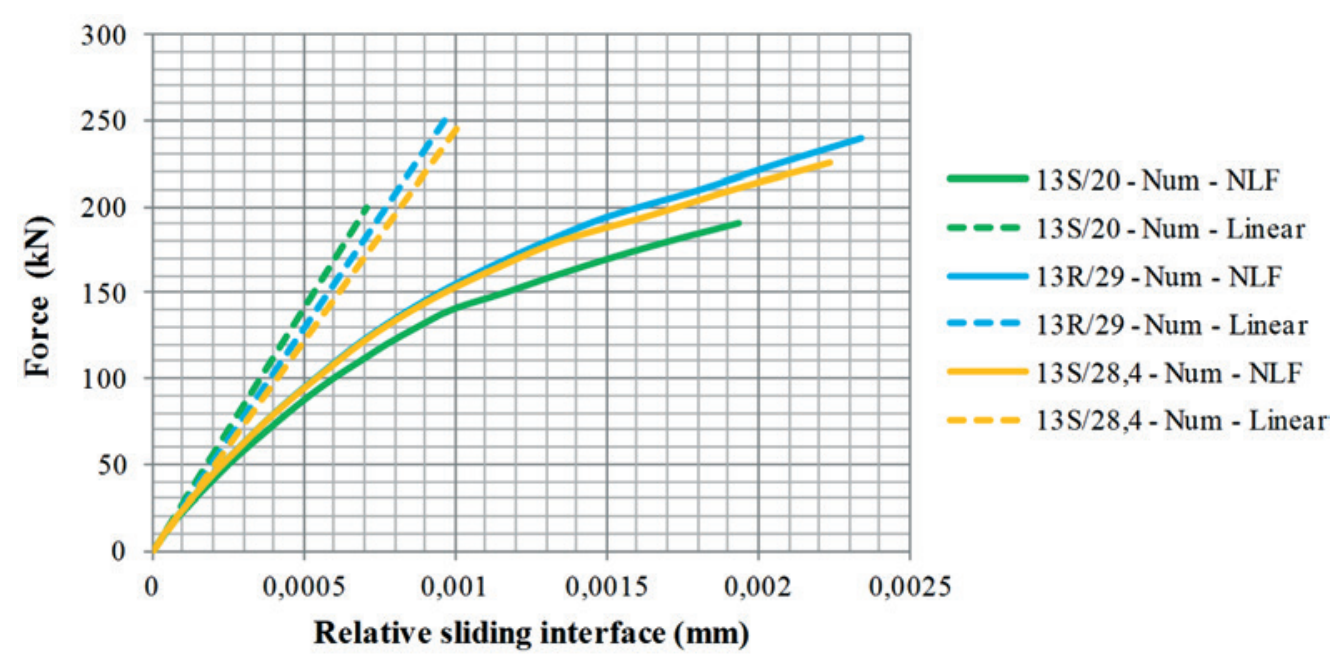

5.1 Results of numerical simulations of the models subjected to direct shear stress

The next sections describe the numerical results of direct shear strength as a function of the influence of interface roughness, of width and strength of concrete in the filled region, and of the dowel effect.

\subsubsection{Influence of interface roughness and strength of concrete fill}

Figure 13 illustrates the linear and nonlinear physical behavior $(\mathrm{NLF})$ of series $\mathrm{C}, \mathrm{F}$ and I $(13 \mathrm{~cm})$ with respect to the influence of interface roughness and strength of concrete fill. Series $A, D$ and $G$ $(7 \mathrm{~cm})$ and $\mathrm{B}, \mathrm{E}$ and $\mathrm{H}(9 \mathrm{~cm})$ showed the same behavior pattern. For the same loading level, models $\mathrm{C}$ and I, with smooth interfaces, show a higher relative displacement than series $F$ with rough interface. It is worth noting that, for the same interface surface, the model with the lowest compressive strength in the filled region (CPC) showed higher displacements.
The numerical rupture force also increases due to roughness of the interface and the concrete compressive strength, varying between 18 and $26 \%$ of changing. The roughness interface contribution is less than the concrete compressive strength in the filled region (CPC), about $7 \%$.

\subsubsection{Influence of the variation in width of the CPC filled region}

Figure 14 compares the results of the influence of the width of the region filled with $\mathrm{CPC}$. For the same amount of relative displacement, it was found that the loading level achieved was higher in the models with smaller widths of CPC.

This behavior is explained by the fact that the model with the smaller internal width shows lower stress normal to the interface distributed throughout the section. Conversely, the models that show higher stresses normal to the interface are those with greater widths in the CPC filled region, failing under lower loading. It should be noted that both the higher roughness and higher strength of the concrete fill contribute to the tendency for greater ultimate loading capacity of the model.

\section{Figure 14 - Effect of varying the width of the concrete filled region CPC}

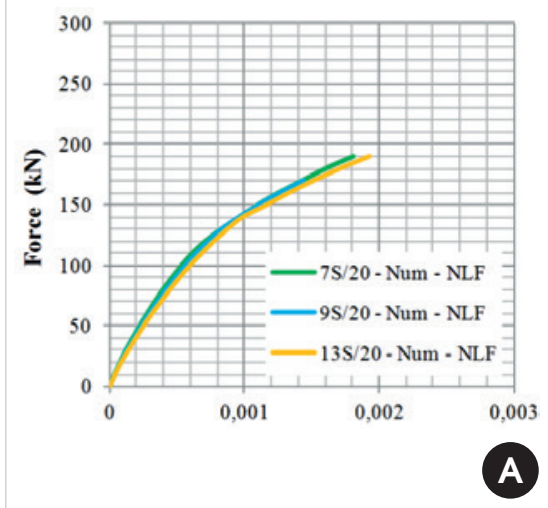

Series $A, B$ and $C$

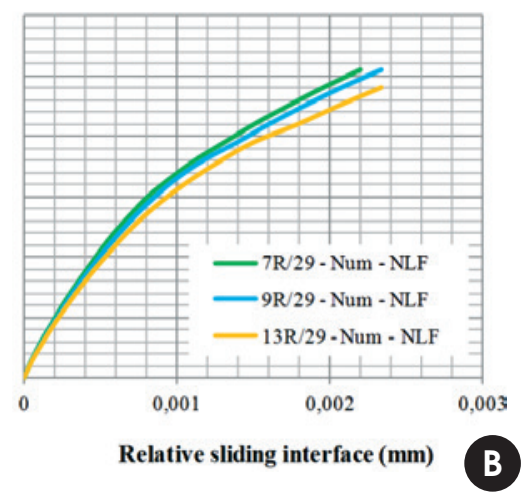

Series C, D and F

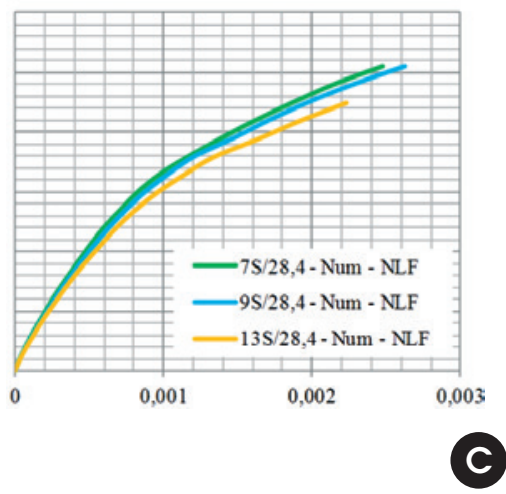

Series $\mathrm{G}, \mathrm{H}$ and I 


\section{Figure 15 - Contribution of reinforcement throughout the interface of series $\mathrm{G}, \mathrm{H}$ and I}

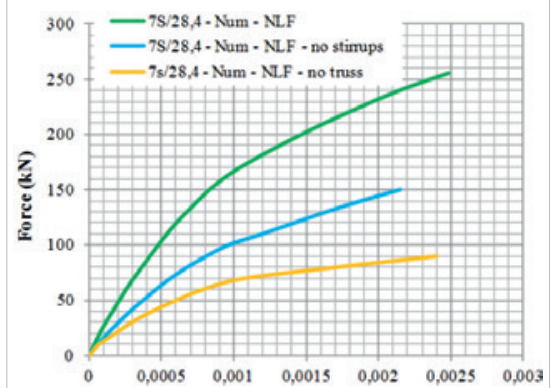

(A)

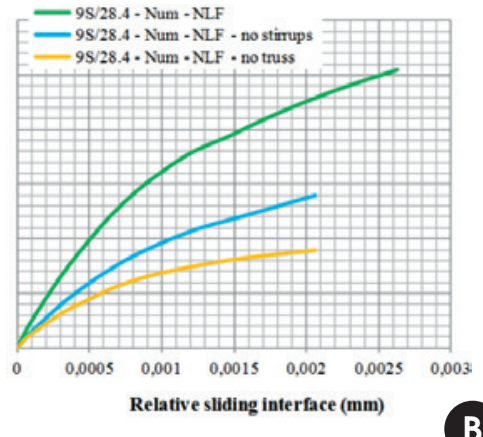

B

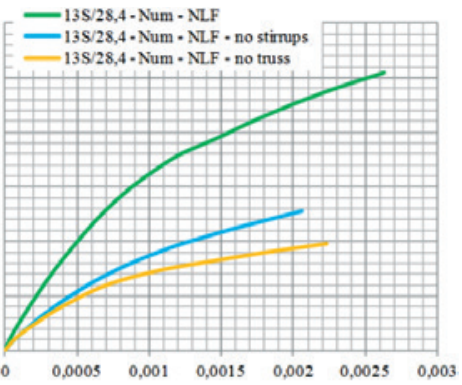

(C)

Series I

Series $G$

Series H

5.2 Cracking of the double lattice panels under direct shear

\subsubsection{Influence of the dowel effect}

To evaluate the influence of the reinforcement that crosses the interface, or the dowel effect on shear strength, three types of situations were analyzed numerically: without stirrups, without lattice, and with lattice and stirrups (Figure 15).

Models with stirrups and lattice withstand a higher level of loading than the other cases. Thus, it is possible to observe the influence of the dowel effect on the shear strength. Models with lattice and without stirrups withstand on average $71 \%$ of the breaking strength of the models with all the reinforcements. Models with stirrups but without lattices reach only $40 \%$ of the ultimate strength of the models with stirrups and lattices. As the width of the region of CPC $(13 \mathrm{~cm})$ increases, the effect of the absence of the stirrups becomes more significant (Figure 15c).
Cracking in the panels subjected to direct shear stress was analyzed in this study for the B Series, since almost all the numerical models showed the same type of cracking. The first crack occurred at the interface of the model under a load of approximately $25 \mathrm{kN}$. In general, the same type of cracking and mechanical behavior obtained in the numerical modeling was observed experimentally (Figure 16).

\section{Comparison of numerical and experimental results}

The numerical and experimental results of the models revealed

\section{Figure 16 - Rupture of the experimental Series B model}

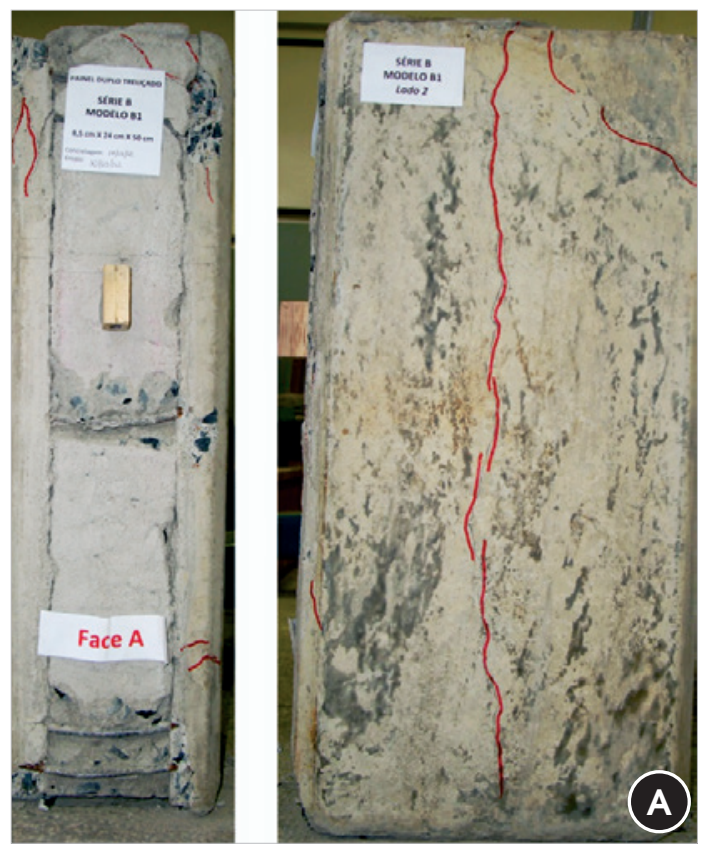

Cracks at rupture (front and lateral face)

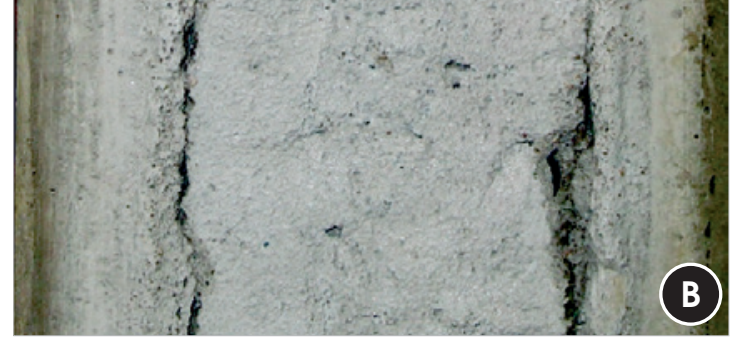

Details of slipping at the concrete interface (PCC and CPC)

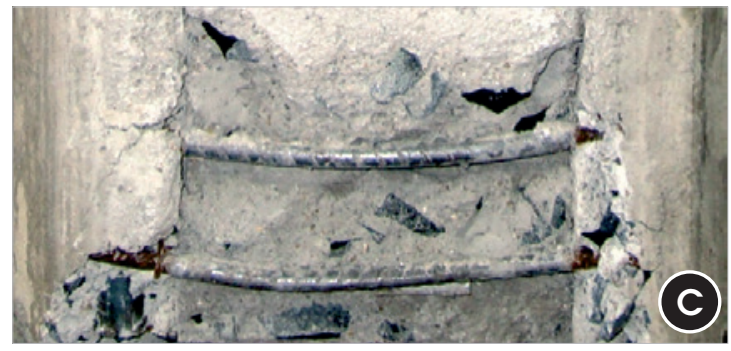

Shear deformation of reinforcement 
Numerical and experimental analysis of the behavior of structural elements composed of double lattice panels filled with cast-in-place concrete

Figure 17 - Comparison of the numerical and experimental results for Series B, D, E, F, G and I
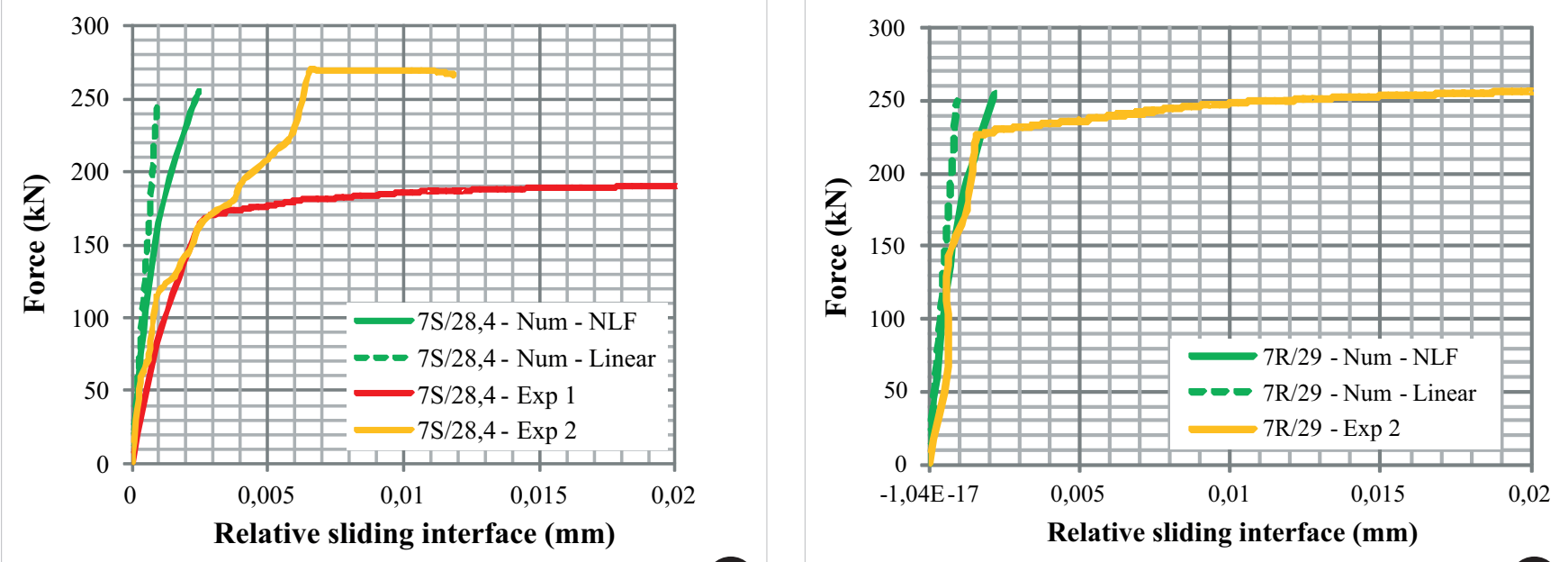

(A)

Series G: Smooth interface-7cm-CPC 28.4 MPa

Series D: Rough interface-7cm-CPC $29 \mathrm{MPa}$
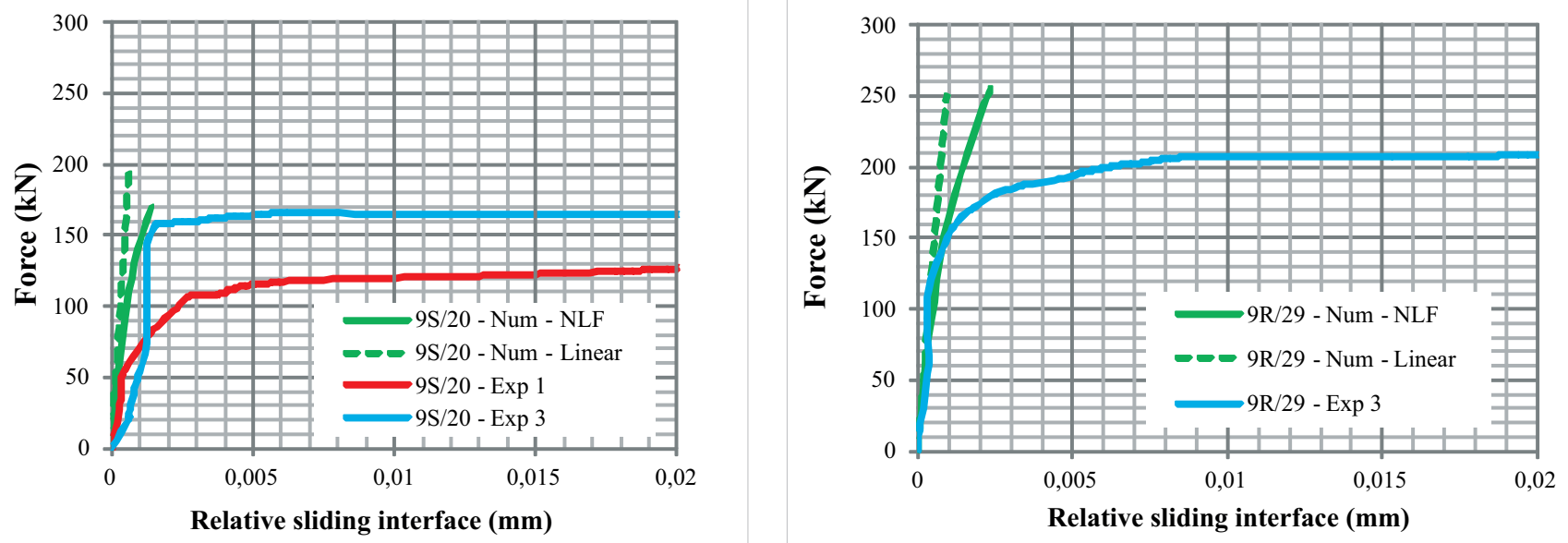

(C)

Series B: Smooth interface-9cm-CPC 20MPa
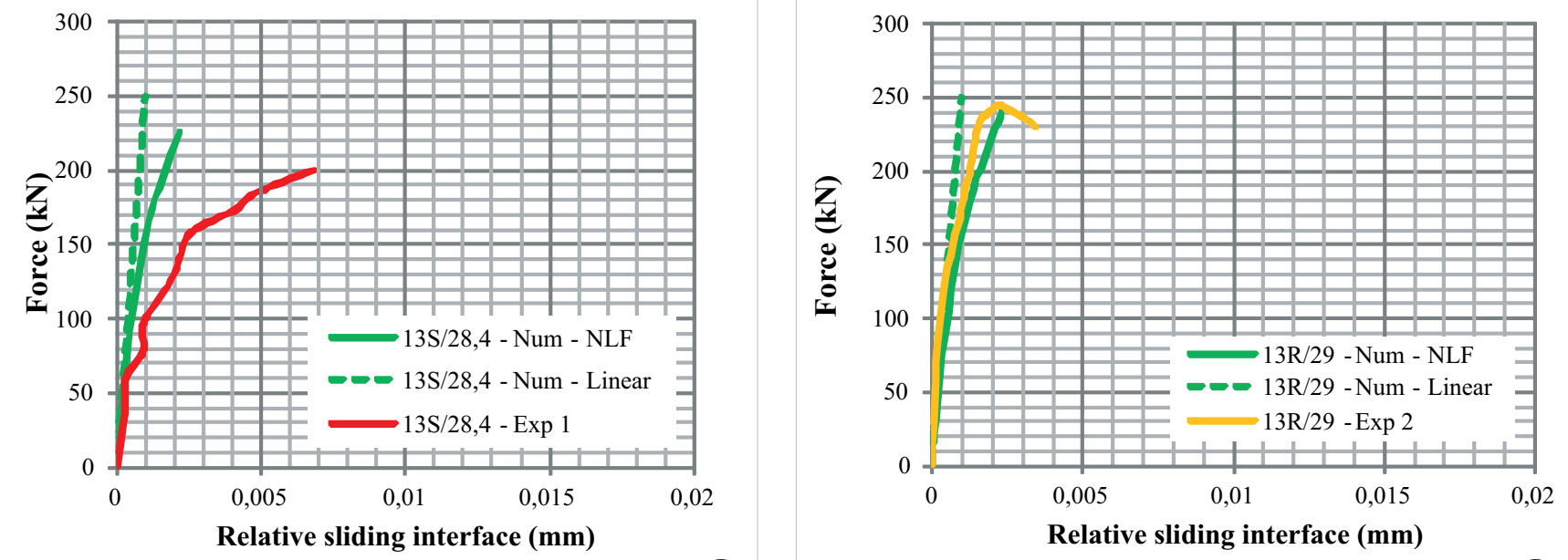

(E) 
low values of interface slipping and shear failure without yielding of reinforcing bars. The linear and nonlinear responses of the models are presented numerically. The rupture strength achieved experimentally for the series varied widely in the tested models. However, this variation was attributed to the small number of prototypes tested for each series. As a matter of fact, a tendency of the increasing of the load-bearing capacity of the models under direct shear stress was observed due the increase in compressive strength of the concrete in the filled region.

Figure 17 illustrates the ratio of force vs. relative slip at the interface indicated by the numerical and experimental results of models under direct shear stress of Series B, D, E, F, G and I. Other series showed very similar results.

The models with smooth interfaces showed higher relative slip than the models with rough interfaces, in order of 2 or 3 times greater (Figure 17a,b and Figure 17e,f). In general, the models with rough interfaces presented relative slipping in the order of $2 \times 10^{-3} \mathrm{~mm}$. The numerical response of the relative sliding interface for the smooth interface tested series showed conservative values compared to the experimental tests. The rough interface series showed a good agreement between experimental and numerical response.

\section{Conclusions}

In general, the results show that the structural set works without significant slip at the interface. The main conclusions are described below.

The analyses of the experimental results under direct shear indicated that the transfer of stresses at the interface occurred with loss of adhesion. This was caused by detachment between the surfaces, frictional and mechanical forces, and the contribution of the dowel effect, until concrete-to-concrete slippage and rupture occurred, with crushing of the precast concrete in the region of the supports.

The surface roughness of the interface bonding region was an important factor in the increase in direct shear strength. In general, the smooth models with lower compressive strength in the filled region showed slippage 2 or 3 times greater at rupture than the relative slip at the interface of the models with rough surfaces;

As for the contribution of the compressive strength of the concrete in the filled region, an increase was observed in the direct shear strength of concrete with higher compressive strengths. Due to the wide dispersion of results for the experimental models, the average value of this contribution could not be determined. In numerical terms, the models with smooth interfaces showed a $36.61 \%$ gain in shear strength in response to the increase in compressive strength of the concrete in the filled region from 20 $\mathrm{MPa}$ to $28.4 \mathrm{MPa}$.

The numerical study indicated that the direct shear strength at the interface was higher in models of smaller width, since they presented lower normal stresses distributed at the interface, thus withstanding higher loading than the other models. Experimentally, due to the small number of tests performed for each variable under analysis, the values of rupture strength varied significantly.

Considering the contribution of each portion of reinforcement crossing the interface, the numerical simulations indicated that the higher the geometric ratio of reinforcement the higher the direct shear strength of the structural model. The models with lattices but without stirrups showed $71 \%$ of the rupture strength of the models with complete reinforcement. This rate dropped to $40 \%$ in the models with only stirrups and without lattices. At break, the stirrup reinforcement of the numerical models under direct shear did not reach the yield point.

\section{Acknowledgements}

The author gratefully acknowledges the Brazilian research funding agency CAPES (Federal Agency for the Support and Improvement of Higher Education) for a master's scholarship awarded for this research and the company PREMON the donation of precast concrete components.

\section{References}

[1] ANSYS RELEASE. Version 11.0 Documentation. SAS IP, Inc ${ }^{\odot ;} 2007$.

[2] ASSOCIAÇÃO BRASILEIRA DE NORMAS TÉCNICAS. NBR 6118: Projeto de estruturas de concreto - Procedimento. Rio de Janeiro: ABNT, 2014.

[3] ASSOCIAÇÃO BRASILEIRA DE NORMAS TÉCNICAS. NBR 9062: Projeto e execução de estruturas de concreto pré-moldado. Rio de Janeiro: ABNT, 2006.

[4] ARAÚJO, D. L. Cisalhamento na interface entre concreto prémoldado e concreto moldado no local em elementos submetidos à flexão. Thesis (Master Science). Escola de Engenharia de São Carlos, Universidade de São Paulo, 1997.

[5] ARAÚJJO, D. L. Cisalhamento Entre Vigas e Lajes Pré-Moldadas Ligadas Mediante Nichos Preenchidos com Concreto de Alto Desempenho. Thesis (Doctor Science). Escola de Engenharia de São Carlos, Universidade de São Paulo, 2002.

[6] BASS, R. A., CARRASQUILLO, R. L., JIRSA, S. O. Shear Transfer Across New and Existing Concrete Interfaces, $\mathrm{ACl}$ Structural Journal, v. 86, n. 4, p. 383-393, jul./aug. 1989.

[7] BENAYOUNE, A., et al. Flexural Behaviour of Pre-cast Concrete Sandwich Composite Panel - Experimental and Theoretical Investigations. Construction and Building Materials, v. 22, p. 580-592, 2008.

[8] EL DEBS, M. K. Concreto Pré-Moldado: Fundamentos e Aplicações. Universidade de São Paulo. São Carlos: EDUSP, 2000.

[9] HOFBECK, J. A., IBRAHIM, I. O., MATTOCK, A. H. Shear Transfer in Reinforced Concrete, ACl Journal, Proceedings, v. 66, n. 2, p. 119-128, feb. 1969.

[10] HSU, T. T. C., MAU, S. T., CHEN, B. Theory of Shear Transfer Strength in Reinforced Concrete, ACI Structural Journal, v. 84, n. 2, p. 149-160, mar./apr. 1987.

[11] KABIR, M. Z. Structural Performance of 3-D Sandwich Panels Under Shear and Flexural Loading. Scientia Iranica, v. 12, n. 4 p. 402-408, oct. 2005.

[12] LACERDA, B. M. Estudo Numérico e Experimental do Comportamento de Painéis Duplos Treliçados Preenchidos com Concreto Moldado no Local. Thesis (Master Science). Universidade Federal de Uberlândia, 2013.

[13] LEONHARDT, F., MÖNNIG, E. Construções de Concreto: princípio básico do dimensionamento de estruturas de concreto armado. Rio de Janeiro: Interciência, 1982. 
[14] OLIVEIRA, D. M. Estudo dos Processos Aproximados Utilizados para a Consideração das Não-linearidades Física e Geométrica na Análise Global das Estruturas de Concreto Armado. Thesis (Doctoral Science). Universidade Federal de Minas Gerais, 2007.

[15] RISSO, M. A. C. Resistência ao Cisalhamento de Ligações de Concreto de Diferentes Idades Providas de Chumbadores de Expansão. Thesis (Master Science). Universidade Federal do Rio de Janeiro, 2008. 